\title{
Addressing the need for a Clean Development Mechanism (CDM) SPECIFIC PROJECT MANAGEMENT STRATEGY
}

\author{
Marco Lotz \\ Graduate School of Technology Management, University of Pretoria
}

Alan Brent

Graduate School of Technology Management, University of Pretoria, Resource Based Sustainable Development, Natural Resources and the Environment, CSIR

\section{Herman Steyn}

Graduate School of Technology Management, University of Pretoria

\begin{abstract}
Clean Development Mechanism (CDM) projects have additional technical, financial and regulatory requirements that are not fully addressed by classic project management approaches. Research has been done on individual novel concepts of the CDM, like additionality, but little has been achieved to address an overall CDM project management approach. CDM and project management literature were reviewed and the South African CDM Industry Association was used as a case study to gain insight into an appropriate CDM specific project management strategy. A stage-gate model was subsequently derived to align classic project management approaches with the additional requirements of CDM projects. Further research will, in time, determine the completeness and practicability of the proposed model.
\end{abstract}

JEL Q51; 52; 58

\section{Table 1}

Abbreviations used in the paper

\begin{tabular}{|l|l|}
\hline \multicolumn{1}{|c|}{ Abbreviation } & \multicolumn{1}{c|}{ Meaning } \\
\hline CDM & Clean Development Mechanism \\
\hline CER & Certified Emission Reduction \\
\hline COP & Conference of the Parties \\
\hline DME & Department of Minerals and Energy \\
\hline DNA & Designated National Authority \\
\hline DOE & Designated Operational Entity \\
\hline EB & Executive Board \\
\hline GHG & Green House Gas \\
\hline IGES & Institute for Global Environmental Strategies \\
\hline IPCC & Intergovernmental Panel on Climate Change \\
\hline PDD & Project Design Document \\
\hline PIN & Project Identification Note \\
\hline
\end{tabular}




\begin{tabular}{|l|l|}
\hline PMBOK & Project Management Body of Knowledge \\
\hline PP & Project Participant \\
\hline SA CDMIA & South African Clean Development Mechanism Industry Association \\
\hline SD & Sustainable Development \\
\hline UN & United Nations \\
\hline UNFCCC & United Nations Framework Convention on Climate Change \\
\hline
\end{tabular}

\section{1 \\ Introduction}

Various pollution reduction incentives exist. One such incentive is the Clean Development Mechanism (CDM) of the United Nations (UN) Kyoto Protocol. In 1997 the Kyoto Protocol was adopted at the Third Session of the Conference of the Parties (COP) to the UN Framework Convention on Climate Change (UNFCCC, 2009). Thereby so called Annex-I-country, or industrialised country, signatories accepted legally binding commitments to reduce Green House Gas (GHG) emissions. The signatory countries agreed to reduce their anthropogenic emissions of GHGs by at least 5 percent below 1990 levels in the commitment period 2008 to 2012. The GHG emissions targeted are $\mathrm{CO}_{2}$, $\mathrm{CH}_{4}, \mathrm{~N}_{2} \mathrm{O}, \mathrm{HFCs}, \mathrm{PFCs}$, and $\mathrm{SF}_{6}$ (UNFCCC, 2009; Zegras, 2007). During the UN conference on climate change in Bali in December 2007, progress was made regarding a post 2012 regulatory framework for climate change. Even the United States, a defiant non-signatory to the Kyoto Protocol, signed the Bali accord (CNN, 2007).

The CDM offers an incentive for GHG emissions reduction for industrialised countries, or their companies, where these countries could earn emissions credits. The incentives of the $\mathrm{CDM}$ for developing countries are acquiring new technology and acquiring foreign capital and accelerated growth. The transfer of moneys is achieved by normal trading. The CDM consequently has two main objectives:

- To mitigate GHG emissions by offering a tradable commodity for proven emission reductions. The tradable commodity is known as Certified Emission Reduction (CER) units.

- To contribute to sustainable development (SD) in developing countries.

A CER is simply the prevention of 1 tonne of $\mathrm{CO}_{2}$ gas emitted. $\mathrm{CO}_{2}$ is not the most potent of GHGs, but is the most common one. Because of the abundance of $\mathrm{CO}_{2}$ the potential green house effect of all GHGs is commonly referenced to that of $\mathrm{CO}_{2}$. As an example, the CDM currently considers the $\mathrm{GHG}$ potential of $\mathrm{CH} 4$ as 21 . The greenhouse gas warming potential ranges according to the time scale considered, e.g. according to the IPCC (2006) a GHG potential of 23 is associated with methane. This implies that, for the purposes of the CDM, 1 tonne of $\mathrm{CH}_{4}$ is equivalent to 21 tonnes of $\mathrm{CO}_{2}$ (UNFCCC, 2009).

Hasselknippe (2003) describes the mechanisms of emissions trading. In essence CERs are traded on the open market at a price driven by supply and demand pertaining to specific projects. The trends in the carbon market are reported by the World Bank (Capoor, 2007), and Michaelowa (2003) provides more information regarding CDM transaction costs. The CDM is governed by the Executive Board (EB) of the UNFCCC (2009), whilst the trading of the CERs is facilitated by the World Bank Carbon Finance Unit (WBCFU, 2009).

Previous researchers have noted some of the complexities associated with CDM projects (Minang, McCall \& Bressers, 2006; Zegras, 2007). These include, but are not limited to:

- The CDM EB has an additional regulatory framework that has to be satisfied above the normal regional, national and international laws, to which conventional projects have to conform. 
- A GHG limiting project can have various CDM projects embedded. This increases the complexity of such projects because all the GHG emissions must be accounted for, but only accounted for once. In other words, it is possible that some emissions are overlooked and not accounted for and some emissions double counted.

- The potential revenue from CERs introduces an added level of complexity to a project's financial model. The reason is simply that GHGs, previously treated as waste, can now have significant financial value.

- The CDM project structure is not historically well known. This is due to the fact that the CDM was developed only after the Kyoto Protocol came into effect. The project management of this relatively new field implies that non-optimised ad hoc project management approaches are common amongst CDM project developers.

This paper focuses on the latter project management aspect of the CDM. The Project Management Body of Knowledge (PMBOK, 2004) defines project management as "the application of knowledge, skills, tools and techniques to project activities to meet project requirements". The objectives of this paper are subsequently to:

- Establish the current formalised state of CDM project management approaches;

- Establish the perceived need for a formalised CDM project management approach; and

- Derive an appropriate generic model to address the specific needs of CDM project management.

\section{2}

\section{CDM opportunities for South Africa and Africa}

It is generally accepted that Africa will not be a major earner of CERs on a global scale (Cosbey, Parry, Browne, Babu, Bhandari, Drexhage \& Murphy, 2005). The estimates of the global CER market share that Africa will have, range between 4 percent and 14 percent
(Haites, 2004), with 5 percent being a common figure used (Ellis, Winkler, Corfee-Morlot \& Gagnon-Lebrun, 2007). However, Africa still holds a significant potential for carbon dioxide sequestration through, for example, increased agricultural activities (Ringius, 2002).

Silayan (2005) identifies institutional capacity, including the presence of a Designated National Authority (DNA), as one of the major contributing factors for the successful registration of CDM projects. In general most developing countries with high absolute emissions have built institutional capacity in the form of a DNA; these include China, India, Brazil, South Korea, Indonesia, Mexico and, notably, South Africa as the only country from Africa (Ellis et al., 2007).

Jung (2006) assessed one hundred and fourteen host countries on their CDM attractiveness. The criteria used for Jung's classification were mitigation potential, institutional CDM capacity, and general investment climate. The countries with the highest potential for CDM projects, excluding forestry-related projects, are China, India, Brazil, Argentina, Mexico, Indonesia, Thailand, and South Africa as the only African country with a high rating.

It would then seem that South Africa is perfectly suited to benefit from CDM project activities, although the benefit of CDM for Africa as a whole is limited. Heller and Shukla (2003), however, point out that other countries in the region could potentially emulate South Africa regarding CDM success, and in this way the continent can benefit more from the CDM.

\section{3}

Research approach

A literature review established what steps, processes and/or stages are considered to be necessary for the successful completion of a $\mathrm{CDM}$ project. The main sources of literature were the guidance provided by the CDM Executive Board (EB) of the UNFCCC (2009), and publications of the Institute for Global Environmental Strategies (IGES, 2007). 
The South African CDM Industry Association (SA CDMIA), which consists of consulting firms that actively develop CDM projects as well as other stakeholders, was then engaged as a case study. A questionnaire that was compiled from the reviewed literature formed the basis of the engagement. The purpose of the case study was to establish to what extent project management is formalised in the industry and to identify shortcomings with the project management approaches. The case study, and literature, provided the necessary information to introduce a new model that facilitates the interaction of standard project management approaches with the special needs of CDM project management.

\section{4}

\section{Literature review}

\subsection{The steps required for the successful completion of a CDM project}

The CDM is a project-based approach. Each CDM project is unique, but will have the same generic components and types of parties or stakeholders involved.

The party that is interested in registering a CDM project is referred to as the Project Proponent (PP). The PP can also be a group of parties depending on the commercial arrange- ment of the company/entity with the potential for emissions reductions, the parties/entities with the know-how to develop CDM projects, and potential investors in such projects. Further details of the potential commercial arrangements can be obtained from CDM project developers like Promethium Carbon (2009).

All CDM projects need host country approval before the CDM Executive Board (EB) will start to evaluate the merit of a project. The CDM term used for the governmental entity in the host country that must provide host country approval is the Designated National Authority (DNA). In South Africa the DNA is hosted by the Department of Minerals and Energy (DME, 2008).

An impartial third party is required to validate, to verify and to certify all CDM projects. This impartial third party is known as the Designated Operational Entity (DOE) and has to be accredited by CDM EB for the services it will provide to Project Proponents. Normally these DOEs are auditing firms like PricewaterhouseCoopers (PWC) or TUV (UNFCCC, 2009).

As stated earlier the CDM is governed by the CDM EB. Only the EB can register a CDM project and issue associated CERs.

Figure 1 illustrates the components of a $\mathrm{CDM}$ project, the flow of the project, and the involvement of the various parties discussed.

\section{Figure 1}

Flow diagram of CDM process and party involvement (adapted from UNDP, 2006)

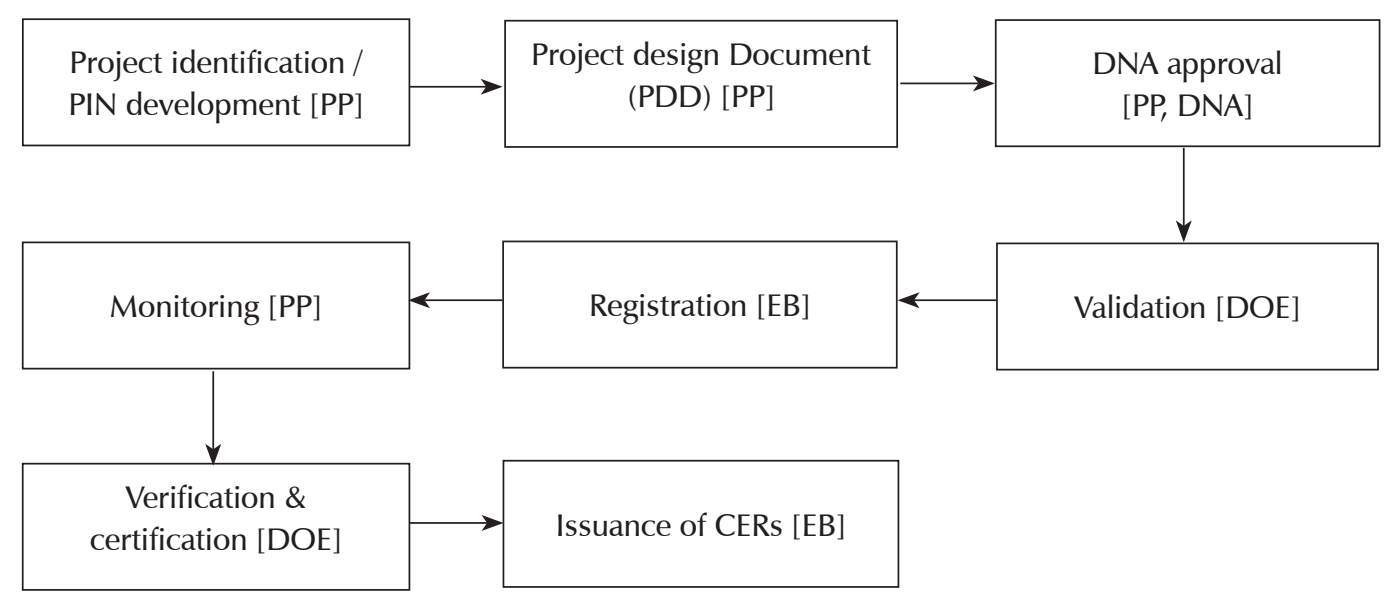

PP - Project Proponent; DNA - Designated National Authority; DOE - Designated Operational Entity; EB - Executive Board 
First, a Project Identification Note (PIN) is drawn up which briefly states the goals and processes to be used in a potential CDM project. In South Africa the PP can at this early stage apply for provisional host country approval from the DNA.

As a next step a Process Design Document (PDD) is required to be submitted by every CDM project. This PDD is a comprehensive document that indicates how an approved CDM methodology will be used to mitigate GHGs in the proposed project activity. If no methodology exists that can be applied to the proposed project activity then a new methodology has to be drafted and approved by the CDM EB as part of the proposed project activity.

The DNA must provide final host country approval when the PDD with the approved methodology has been completed. It is at this stage that a DOE is required to evaluate the proposed project, and if the DOE is satisfied with the methodology and PDD, then it can be submitted to the CDM EB for registration. The final decision for project registration rests solely at the CDM EB.
In order to earn CERs after project registration the PP needs to apply the monitoring plan, as described in the PDD and CDM methodology, to prove that GHG emission reduction was achieved. The verification and certification of this GHG mitigation is then the task of the DOE. Only after the verification and certification by the DOE will the CDM EB issue CERs to the PP.

\subsection{Standard project management approaches}

Obtaining information on the classical project management approach followed today is an easy matter. Various project management models and standards have been developed since the middle of the 20th century. These models and standards include, amongst others, PRINCE2 (OGC, 2005) and PMBOK (2004). There are large similarities amongst classical project management models and/or standards irrespective of which model and/or standard is used. The generalised project management sequence is depicted in Figure 2 (Openlearn, 2009), which is similar to the typical PMBOK (2004) phases in a project lifecycle.

\section{Figure 2}

Generalized project management sequence (Openlearn, 2009)

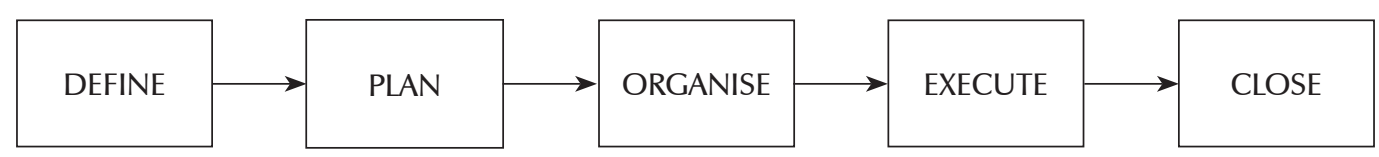

As is indicated in Figure 2, it is commonly accepted that a project can be broken down into stages or phases. Each of these phases then has specific goals that must be achieved and addressed in subsequent decision gates. Collectively the identified phases, and associated decision gates, are known as the project lifecycle (PMBOK, 2004).

Researchers and project management practitioners greatly differ on the project phases identified regarding the number and terminologies of stages (Brent \& Petrick, 2007). The PMBOK (2004) states that the identified phases generally define the following: technical work to be accomplished during each phase; when deliverables are to be generated during each phase; how each deliverable is reviewed, verified and validated; what parties are involved during each phase; and how to control and evaluate each phase (in a decision-making gate).

\subsection{Aligning specific CDM project management requirements with standard project management approaches}

Novel aspects of emissions reduction projects have been researched. These aspects include the influence of CDM transaction costs (Michaelowa, Stronzik, Eckermann \& Hunt, 
2003) and the contentious issue of CDM additionality (Shrestha \& Timilsina, 1999; Gustavsson, Karjalainen, Marland, Savolainen, Schlamadinger \& Apps, 2000). The research into these individual aspects has highlighted the need for an overall strategy regarding the management of CDM projects.

The intricacy of stakeholder engagement is a further important aspect. Brown and Corbera (2003) have used a stakeholder multi-criteria scheme to explore the range of stakeholders, their roles, and their interests and perspectives, based on carbon sequestration by means of a forestry project in Mexico. However, an integrated strategy to manage all the stakeholders was not developed.

Haites and Yamin (1999) have argued that the number of registered CDM projects and the ease of implementation will benefit from a flexible pragmatic approach. They state that: "there is no right way of doing business under the CDM". This statement indicates a lack of structure in managing CDM projects and shows the ad hoc interventions that characterised early CDM project management approaches. Furthermore, ZhongXiang (2005) states that developing countries typically lack a "clear institutional structure" and an "implementation strategy" system for application, approval, and implementation of CDM projects. ZhongXiang (2005) concludes that through capacity building aspects like established streamlined and transparent $\mathrm{CDM}$ procedures, including sound governance, must be developed through an integrated framework.

The only attempt at a comprehensive framework to CDM project management was developed by the European Bank for Reconstruction and Development (Ecofys, 2004). Their project management framework addresses the additional requirements posed by CDM project management as illustrated in Table 2.

In the "Feasibility Assessment" phase the applicability of the CDM to the proposed project must be investigated. Issues like the economic viability of the project without CDM registration must be answered. The number of potential CERs and the influence of these credits on the projected project revenue must be quantified.

During the "Project Structuring Phase" additional documentation, like the project design document (PDD), must be completed. During this phase the contribution of the proposed CDM project to the sustainable development of the host country must also be addressed.

Table 2

Additional requirements in the CDM project management process (adapted from Ecofys, 2004)

\begin{tabular}{|c|c|}
\hline Conventional project cycle & Additional CDM requirements \\
\hline 1. Project identification & \\
\hline $\begin{array}{l}\text { 2. Feasibility assessments } \\
\text { Project design } \\
\text { Environmental feasibility } \\
\text { Technical feasibility } \\
\text { Financial feasibility } \\
\text { Identify partners }\end{array}$ & $\begin{array}{l}\text { Preliminary assessment of possible delivery of credits } \\
\text { Preliminary assessment of possibility to monitor } \\
\text { emissions }\end{array}$ \\
\hline $\begin{array}{l}\text { 3. Project structuring phase } \\
\text { Contracts } \\
\text { Power purchase agreements } \\
\text { Governmental permits } \\
\text { Preparation of environmental impact assessment (EIA) }\end{array}$ & $\begin{array}{l}\text { Development of project design document (PDD) } \\
\text { Organisation of public consultation } \\
\text { Development and validation of baseline and } \\
\text { monitoring plan }\end{array}$ \\
\hline
\end{tabular}




\begin{tabular}{|c|c|}
\hline $\begin{array}{l}\text { Environmental permits } \\
\text { Building permits } \\
\text { Arranging finance and signing agreements (grants, } \\
\text { loans, etc.) }\end{array}$ & \\
\hline $\begin{array}{l}\text { 4. Implementation phase } \\
\text { Constructing or upgrading plant / facilities }\end{array}$ & Installing monitoring facilities \\
\hline $\begin{array}{l}\text { 5. Operational phase } \\
\text { Monitoring and evaluation: } \\
\text { Financial, environmental and technical aspects }\end{array}$ & $\begin{array}{l}\text { Monitoring and verification and/or certification of } \\
\text { emission reductions }\end{array}$ \\
\hline
\end{tabular}

The complexity of these additional project management requirements is increased due to the distributed decision process that includes the Project Proponent, Designated National Authority, Designated Operational Entity, and the CDM Executive Board. In other words, the shortcoming of the Ecofys (2004) framework is the lack of efficiency of classical project management approaches to address the specific needs of the various stakeholders in Figure 1.

\subsection{Benefits of aligning CDM project management with standard project lifecycle phases}

Aligning the CDM project process and lifecycle phases is a field of study not widely exploited yet. The following benefits are envisaged for aligning and integrating the CDM project process and project lifecycle phases:

- The ad hoc project management commonly found in CDM projects can be structured;

- The need to force CDM project management into standard project management models designed for other types of projects will be alleviated; and

- The clear-sightedness of CDM projects will become more apparent to parties who are not CDM experts.

\section{5}

\section{Case study - the SA CDMIA}

Little, Maxwell and Sutherland (2007) have described the South African CDM landscape to some extent. Little et al. (2007) interviewed thirty "experts involved in the South African CDM process" and focused not on the management of the CDM process, but rather the identification of factors that inhibit and accelerate the CDM process in South Africa. As an extension of the study of Little et al. (2007) the South African CDM Industry Association (SA CDMIA), which was being formed during 2007, was engaged as a case study. A questionnaire consisting of twelve high level questions, and some subquestions, was used as basis for the engagement. One hundred potential affiliates of the then informal SA CDMIA were targeted. Only eight responded positively to the engagement.

The limited response is mainly attributable to the lack of formal structure of the SA CDMIA at the stage of the investigation; there was no single point of entry to engage the SA CDMIA in its entirety, although this is now changing. Those affiliates that did not respond positively also highlighted a concern about the potential use of sensitive information; by answering some of the questions posed in the questionnaire would easily have identified the specific role-player in the small SA CDMIA community. This has been considered as to the information that is supplied about the case.

Although the low number of responses means that the SA CDMIA case study does not statistically represent the South African project management landscape, some insight can be gained regarding the maturity of the SA CDMIA, and specifically how CDM projects are viewed and approached.

In evaluating the answered questionnaires it was found that the positive respondents had been involved in at least three CDM projects already 
registered. At the time of the investigation South Africa had ten registered CDM projects in total as verified by the DNA (DME, 2009). The respondents further indicated that more than four CDM projects per respondent were in different stages of development, i.e. a total of at least thirty-two new projects; the total number of CDM projects under development in South Africa at the time of the investigation could not be determined.

The questionnaire required the respondents to indicate their relative fields of expertise pertaining to the technical, financial and regulatory aspects of $\mathrm{CDM}$ project management. Six of the eight respondents considered themselves partial towards the technical and financial aspects of CDM projects as opposed to the regulatory aspects. Since provincial/regional, national, international and CDM-specific regulatory approval could all be necessitated, depending on the specific project, the lack of regulatory associated expertise in the SA CDMIA is noteworthy. To this end the questionnaire also aimed at establishing where CDM project developers and related parties perceived bottlenecks in the successful completion of a CDM project. The perceived bottlenecks were also divided into financial, technical and regulatory aspects, and a distinction was made between domestic (South African) and foreign perceived bottlenecks. The South African regulatory environment was seen as the single largest bottleneck. This is true even of the efforts of the South African DNA to facilitate the development of CDM projects. Little et al. (2007) also identified the regulatory aspects, i.e. foreign, local and CDMspecific, as major inhibitors. The bottleneck perceived as second largest was foreign technical requirements due to South Africa's dependence on foreign technological imports. Neither local nor foreign financial requirements were viewed as priority bottlenecks. This outcome differs from the outcomes of Little et al. (2007); they document "Africa (is) not an investment destination" as the $4^{\text {th }}$ highest of a total of fiftysix identified inhibitors/facilitating factors. Even without a local versus foreign breakdown it was clear that financial concerns were considered to be the least important in the South African CDM environment. Given the expertise of the respondents does bring into question whether the perceived importance of regulatory bottlenecks is real or whether a lack of regulatory expertise on the part of the respondents induces a higher perceived risk of the regulatory aspect of CDM projects.

In terms of project management approaches, the following two issues were highlighted in the SA CDMIA:

- Only three of the eight respondents indicated that they follow a formalised CDM project management approach although seven of the eight respondents indicated a perceived need for such an approach. With a lack of formalised CDM project management it was deduced that most project management is done on an ad hoc basis.

- Of the eight respondents, five indicated that they had a dedicated person/group acting as project manager for CDM projects. All five positive respondents concluded that the person/group acting as project manager succeeded in facilitating the development of the CDM projects.

From the comments received from the respondents regarding what specific project management models were used, two distinct approaches became clear (see Table 3):

- In the one approach CDM projects were forced to conform to a project management strategy or model that would be used by the respondents in other types of projects. In doing so the need for project management conformity overruled practical project management considerations.

- On the other hand some respondents stated that the uniqueness of every CDM project implied that ad hoc project management was the only realistic strategy.

These issues and comments were useful to derive a proposed CDM project management model. 


\section{Table 3}

Summary of comments regarding CDM project management models used and why the specific models are in use

\begin{tabular}{|c|c|}
\hline First approach: & Second approach: \\
\hline $\begin{array}{l}\text { Force existing project management approaches on CDM } \\
\text { projects }\end{array}$ & $\begin{array}{l}\text { Deal with CDM projects in a purely ad hoc } \\
\text { fashion }\end{array}$ \\
\hline Comments received and reason for approach: & Comments received and reason for approach: \\
\hline $\begin{array}{l}\text { Some companies used an "internal project management } \\
\text { system" or "internal developed standard" }\end{array}$ & $\begin{array}{l}\text { Projects are very diverse, with different } \\
\text { approach needed for each one }\end{array}$ \\
\hline $\begin{array}{l}\text { These project management systems were based on } \\
\text { company "political decisions" }\end{array}$ & $\begin{array}{l}\text { Various role players have their own systems that } \\
\text { don't always integrate }\end{array}$ \\
\hline $\begin{array}{l}\text { It was stated that "all projects need to conform to this" } \\
\text { internal "standard" }\end{array}$ & $\begin{array}{l}\text { Inadequate training/experience in project } \\
\text { management }\end{array}$ \\
\hline
\end{tabular}

\section{6}

\section{Proposed CDM project management model and application}

The indicative findings and insights gained from the literature review and the case study were merged to derive an appropriate CDM-specific project management model, which is structured around the conventional stage-gate approach. The purpose of this model is to alleviate the perceived and real bottlenecks of CDM projects. A stage-gate model consists of project stages or phase followed by gates. Each phase is treated as a discreet separate entity (Perez \& Enkel, 2007) as if each phase was a separate project. The gates act as go/no-go points after evaluation of the objectives of a phase (Tingström, Swanström \& Karlsson, 2006). Gates are also used for project portfolio ranking purposes. The reasoning is that scarce resource will be better allocated to more promising projects (Cooper, 1999). Figure 3 is a graphical representation of the proposed stage-gate model.

In total thirteen phases were identified interlinked with ten gates. After the evaluation of gate ten the project returns to phase nine for the monitoring of data for another year as determined by the Process Design Document (PDD) and specific CDM methodology. This loop is then executed for the duration of CDM project registration with the Executive Board (EB).

The phases, which have to be completed by parties other than the Project Proponent (PP) were lumped together and indicated as "External phases." These phases are completed by entities like the Designated Operational Entity (DOE), Designated National Authority (DNA), and others.

Only the summarised stage-gate flowchart is shown in Figure 3 for brevity. Each phase consists of certain objectives that have to be achieved during each phase. The evaluation of how successful each phase was, is done during the gate analysis that follows on the specific phase/s. The gate consists of Go/Kill criteria and Ranking criteria. Table 4 provides an example of the criteria for phase two. Go/Kill criteria imply that certain objectives must be completed before the next stage can start. If the Go/Kill criteria can not be achieved then the project is stopped. Stages during which all Go/Kill criteria were successfully completed now enter the Ranking part of the gate. Specific ranking criteria were established for each gate. A score is given to each ranking criterion to determine more favourable projects. Weights can also be applied to the ranking criteria that can be determined internally by model users so as to fit specific company needs, policy and resources. 


\section{Figure 3}

Developed stage-gate model for CDM project management An example of the feasibility assessment of phase 2 and associated Go/Kill and Ranking criteria for gate 2 are provided in Table 4

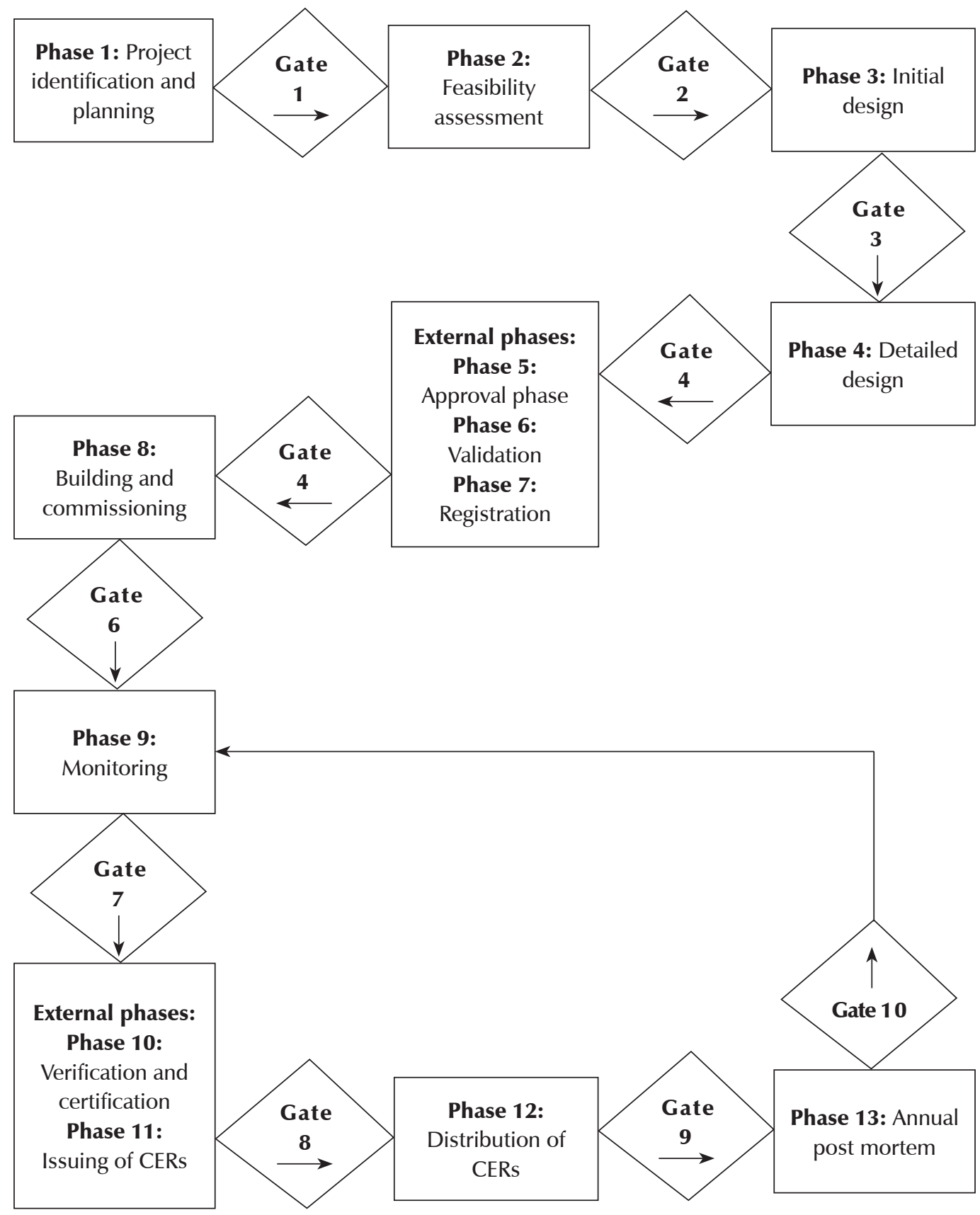




\section{Table 4}

Phase two feasibility assessment and the criteria for gate two

\begin{tabular}{|c|c|c|c|c|}
\hline Phase name & \multicolumn{4}{|c|}{ 2. Feasibility assessment } \\
\hline \multirow{5}{*}{$\begin{array}{l}\text { Purpose of } \\
\text { project phase }\end{array}$} & 1 & \multicolumn{3}{|c|}{ Clarify the need for the project (revenue / corporate responsibility / etc.) } \\
\hline & 2 & \multicolumn{3}{|l|}{ Do an initial estimate of the emission reductions } \\
\hline & 3 & \multicolumn{3}{|c|}{ Assess what is necessary in monitoring the inputs to calculate emission reductions } \\
\hline & 4 & \multicolumn{3}{|c|}{ Do initial assessment of project risk (financial, technical and regulatory) } \\
\hline & 5 & \multicolumn{3}{|l|}{ Obtain initial approval from local DNA } \\
\hline Gate 2 criteria & No & Criteria & No & Yes \\
\hline \multirow[t]{4}{*}{ Kill/Go criteria } & 1 & Is there a need for this project? & Kill & Go \\
\hline & 2 & $\begin{array}{l}\text { Does the initial emission reduction warrant a } \\
\text { CDM project? }\end{array}$ & Kill & Go \\
\hline & 3 & Is the project risk level acceptable? & Kill & Go \\
\hline & 4 & $\begin{array}{l}\text { Are all inputs required measurable / } \\
\text { obtainable? }\end{array}$ & Kill & Go \\
\hline \multirow[t]{4}{*}{ Comments } & 1 & \multicolumn{3}{|c|}{$\begin{array}{l}\text { Various strategic reasons can exist for proposed emissions reduction projects. } \\
\text { Clarifying the need for these projects will help in obtaining backing from } \\
\text { management. }\end{array}$} \\
\hline & 2 & \multicolumn{3}{|c|}{$\begin{array}{l}\text { If the estimated emissions reduction achievable is too small then no CDM project } \\
\text { exists. The project proponents should decide what they consider to be the lower } \\
\text { cut off value regarding emissions reductions achieved. }\end{array}$} \\
\hline & 3 & \multicolumn{3}{|c|}{ Projects should be stopped as soon as project risk reaches unacceptable levels. } \\
\hline & 4 & \multicolumn{3}{|c|}{$\begin{array}{l}\text { It is foreseeable that insufficient data are available to accurately establish emission } \\
\text { reductions. If the emissions reductions are not measurable then the project should } \\
\text { be stopped. }\end{array}$} \\
\hline \multirow[t]{3}{*}{ Ranking criteria } & No & \multicolumn{2}{|l|}{ Criteria } & Score \\
\hline & 1 & \multicolumn{2}{|c|}{ Are there any perceived or real objections from the local DNA? } & \\
\hline & 2 & \multicolumn{2}{|l|}{ How attractive is the amount of CERs earned? } & \\
\hline \multirow[t]{2}{*}{ Comment } & 1 & \multicolumn{3}{|c|}{$\begin{array}{l}\text { In the development of this model it is proposed to get initial host country approval } \\
\text { for a project at the earliest possible stage. This will help in managing project risk } \\
\text { from the start although host country approval is according to CDM guidelines not } \\
\text { strictly necessary at such an early stage. }\end{array}$} \\
\hline & 2 & \multicolumn{3}{|c|}{$\begin{array}{l}\text { The amount of carbon credit revenue earned is a direct function of the amount of } \\
\text { CERs obtainable. All else being equal, projects producing more CERs should take } \\
\text { preference. }\end{array}$} \\
\hline
\end{tabular}

\subsection{Potential inefficiencies of the derived stage-gate model}

A Kill/Go criterion is binary. To terminate a CDM project according to this measure could be seen as extremely harsh. This is especially true the further a project progresses as a loss of time and money will certainly be incurred if projects are terminated. It is then important to stress that all possible actions must be taken to satisfy the Kill/Go criteria. It is only when no acceptable solution can be found that a project 
should be terminated. This approach ensures that lingering unsuccessful projects are taken off the project portfolio so as to maximise available project development resources.

According to the derived model many parties, i.e. all project proponents, DNA, DOE, CDM $\mathrm{EB}$, financial institutions, etc., can execute the Kill/Go criteria. This decentralised control structure induces risk as the number of parties increases. However, the decentralised control of a CDM project exists whether the project management structure points it out or not. What the stage-gate then actually achieves is the coordination of the stakeholders and other parties involved during the development of a CDM project, which is seen as an advantage. Getting all the stakeholders and parties involved to agree can be tedious. It is therefore imperative for the stage-gate model to identify only the relevant stakeholders and parties involved in each stage or phase. By doing so, the number of parties and stakeholders per stage, and thus the level of decentralised control, can be minimised.

Bessant, Lamming, Noke and Phillips (2005) argue that stage-gate models do not manage "breakthrough innovations" effectively. This is not seen as detracting from the appeal to use a stage-gate model since CDM projects are arguably not 'breakthrough innovations'. CDM projects have to follow a strict predetermined regulatory path, which suits the stage-gate model approach.

The uniqueness of each CDM project can lead to incompatibilities with project management models. For this reason a more generic approach to stages and gates was proposed in the derived stage-gate model. It is foreseen that CDM projects will greatly differ in the amount of time and money required per stage.

\section{7}

\section{Conclusions and recommendations}

A literature review was undertaken to investigate the CDM project management landscape. This literature review indicated that various CDM specific concepts, for example additionality, have been researched at length. In contrast very little could be found regarding the overall alignment of special CDM project requirements to classical project management practices.

The South African CDM Industry Association (SA CDMIA) was engaged as a case study to gain further insights in terms of the views and approaches to CDM project management in South Africa. A questionnaire formed the basis of the engagement and eight affiliates of the SA CDMIA participated.

From the literature review and the additional information obtained from the case study a stagegate model was derived to specifically address the complexities and additional requirements of the CDM process, and align these requirements, and applicable stakeholders, with conventional project management practices. The derived stage-gate model is unique in that it stipulates criteria for the termination of projects and a separate set of criteria, which is used to rank the attractiveness of a portfolio of projects.

It is recommended that further research be undertaken to demonstrate the usefulness and applicability of the derived stage-gate model regarding:

- The benefits of the alignment of classical project management approaches with the additional requirements of CDM project;

- The completeness of the model; and

- The management of stakeholders and other parties that can exercise Kill/Go gate criteria.

These aspects are currently being investigated by practically applying the model in the South African CDM industry over time.

\section{References}

BESSANT, J., LAMMING, R., NOKE, H. \& PHILLIPS, W., 2005. Managing innovation beyond the steady state. Technovation, 25(12): 1366-1376. BRENT, C. \& PETRICK, W., 2007. Environmental impact assessment (EIA) during project execution phases: towards a stage-gate project management model for the raw materials processing industry of the energy sector. Impact Assessment and Project Appraisal, 25(2): 111-122.

BROWN, A. \& CORBERA, E., 2003. Exploring equity and sustainable development in the new carbon economy. Climate Policy, 3(1): 41-56. 
CABLE NEWS NETWORK (CNN), 2007. http:// CNN.com/asia [last accessed 15 December 2007]. COOPER, R.G., EDGETT, S.J. \& KLEINSCHMIDT, E.J., 1999. New product portfolio management: practices and performance. Journal of Product Innovation Management, 16(4): 333-351.

COSBEY, A., PARRY, J., BROWNE, J., BABU, Y.D., BHANDARI, P., DREXHAGE, J. \& MURPHY, D., 2005. Realizing the development dividend: making the CDM work for developing countries. International Institute for Sustainable Development (IISD). http:// www.iisd.org/climate/global/dividend.asp [last accessed 23 March 2009].

DEPARTMENT OF MINERALS AND ENERGY, SOUTH AFRICA (DME) 2009. http://www.dme.gov. za/dna/index.stm [last accessed 23 March 2009]. ECOFYS, 2004. Ecofys introduction guide: clean development mechanism projects in the early transition countries. http://www.ppcenvironment.org/assets/ resources/ Workshop\%20 introduction $\% 20$ manual\%20 extended.pdf [last accessed 23 March 2009]. ELLIS, J., WINKLER, H., CORFEE-MORLOT, J. \& GAGNON-LEBRUN, F., 2007. CDM: Taking stock and looking forward. Energy Policy, 35(1): 15-28. EGGLESTON, H.S., BUENDIA, L., MIWA, K., NGARA, T. \& TANABE, K., 2006. IPCC guidelines for national greenhouse gas inventories. Prepared by the National Greenhouse Gas Inventories Programme. http://www.ipcc-nggip.iges.or.jp [last accessed 23 March 2009].

GUSTAVSSON, L., KARJALAINEN, T., MARLAND, G., SAVOLAINEN, I., SCHLAMADINGER, B. \& APPS, M., 2000. Project-based greenhouse-gas accounting: guiding principles with a focus on baselines and additionality. Energy Policy, 28(13): 935-946.

HAITES, E. \& YAMIN, F., 1999. The clean development mechanism: proposals for its operation and governance. Global Environmental Change, 10(1): 27-45.

HAITES, E., 2004. Estimating the market potential for the Clean Development Mechanism: review of models and lessons learned. PCFplus Report 19, http://www. iea.org/textbase/papers/2004/cdm.pdf [last accessed 23 March 2009].

HASSELKNIPPE, H., 2003. Systems for carbon trading: an overview. Climate Policy, 3(2): 43-57. HELLER, T.C. \& SHUKLA, P.R., 2003. Development and climate: engaging developing countries. In Beyond Kyoto: advancing the international effort against climate change. Pew Center on Global Climate Change, http:// pesd.stanford.edu/publications/development_and_ climate_engaging_developing_countries/[last accessed 23 March 2009].

INSTITUTE FOR GLOBAL ENVIRONMENTAL
STUDIES (IGES), 2007. CDM in charts, ver 4.0. http://www.iges.or.jp/en/cdm/report01.html [accessed 23 March 2009].

JUNG, M. 2006. Host country attractiveness for CDM non-sink projects. Energy Policy, 34: 2173-2184.

LITTLE, G., MAXWELL, T. \& SUTHERLAND, M., 2007. Accelerating the implementation of the clean development mechanism in South Africa. South African Journal of Economic and Management Sciences, 10(4): 395-411.

MICHAELOWA, A., STRONZIK, M., ECKERMANN, F. \& HUNT, A., 2003. Transaction costs of the Kyoto mechanisms. Climate Policy, 3(3): 261-278.

MINANG, P.A., MCCALL, M.K. \& BRESSERS, H.T.H.A, 2007. Community capacity for implementing clean development mechanism projects within community forests in Cameroon. Environmental Management, 39(5): 615-630.

OFFICE OF GOVERNMENT COMMERCE, UNITED KINGDOM (OGC), 2005. Managing successful projects with PRINCE2: The PRINCE2 Manual. http://www. ogc.gov.uk/prince2/ [accessed 23 March 2009].

OPENLEARN, 2007. Image of project typical lifecycles. http://openlearn.open.ac.uk/file. php/2338/T205_2_ 008i.jpg, [accessed 23 March 2009].

PMBOK ${ }^{\circledR} 2004$. A guide to project management body of knowledge. Project Management Institute, http://www. pmi.org, [accessed 23 March 2009].

PROMETHIUM CARBON, 2009. < http://www.

promethium.co.za/commercial.html>, last accessed 23 March 2009.

RINGIUS, L., 2002. Soil carbon sequestration and the CDM: opportunities and challenges for Africa. Climatic Change, 54: 471-495.

SHRESTHA, R.M. \& TIMILSINA, G.R., 2002.

The additionality criterion for identifying clean development mechanism projects under the Kyoto Protocol. Energy Policy, 30 (1): 73-79.

SILAYAN, A., 2005. Equitable distribution of CDM projects among developing countries. Hamburg Institute of International Economics, < http://www. econpress.de/Forschung/ Publikationen/Report/2005/ Report255.pdf>, last accessed 23 March 2008. TINGSTRÖM, J., SWANSTRÖM, L. \& KARLSSON, R., 2006. Sustainability management in product development projects - the ABB experience. Journal of Cleaner Production, 14(15): 1377-1385.

UNITED NATIONS DEVELOPMENT

PROGRAMME (UNDP), 2006. The clean

development mechanism, an assessment of progress. $<$ http://www.energyand environment. undp.org/ undp/index.cfm ? module $=$ Library $\&$ page $=$ Document 
\&DocumentID $=5883>$, last accessed 23 March 2009. UNITED NATIONS FRAMEWORK CONVENTION ON CLIMATE CHANGE

(UNFCCC)., 2009. < http://cdm.unfccc.int/>, last accessed 23 March 2009.

WORLD BANK CARBON FINANCE UNIT

(WBCFU), 2009. < http://wbcarbonfinance.org/ >, last accessed 23 March 2009.
ZEGRAS, P.C., 2007. As if Kyoto mattered: the clean development mechanism and transportation. Energy Policy, 35(10): 5136-5150.

ZHONGXIANG ZHANG, 2005. Toward an effective implementation of clean development mechanism projects in China. Energy Policy, 34(18): 3691-3701. 